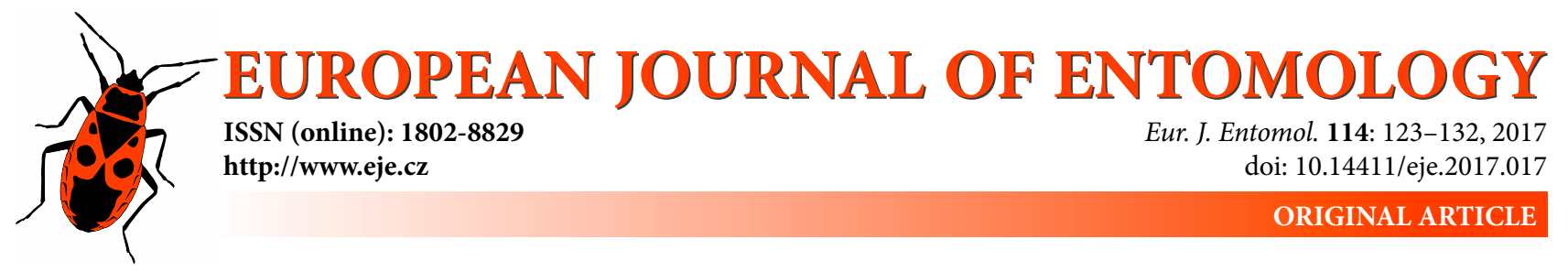

\title{
A comparison of methods for sampling aquatic insects (Heteroptera and Coleoptera) of different body sizes, in different habitats using different baits
}

\author{
Nataša TURIĆ ${ }^{1}$, Martina TEMUNOVIĆ ${ }^{2,3}$, Goran VIGNJEVIĆ ${ }^{1}$, JASENKa ANTUNOVIĆ DUNIĆ ${ }^{1}$ and ENRIH MERDIĆ ${ }^{1}$ \\ ${ }^{1}$ University Josip Juraj Strossmayer in Osijek, Department of Biology, Cara Hadrijana 8/A, HR-31000 Osijek, Croatia; \\ e-mails: nturic@biologija.unios.hr, gvignjevic@biologija.unios.hr, jantunovic@biologija.unios.hr, enrih@biologija.unios.hr \\ ${ }^{2}$ University of Zagreb, Department of Forest Genetics, Dendrology and Botany, Svetošimunska 25, HR-10000 Zagreb, Croatia; \\ e-mail: martina.temunovic@gmail.com \\ ${ }^{3}$ Association BIOM, Croatian Institute for Biodiversity, Preradovićeva 34, HR-10000 Zagreb, Croatia
}

Key words. Heteroptera, Coleoptera, aquatic insects, sampling, comparison, bait, body size, habitat type, species richness

\begin{abstract}
Although various methods exist for sampling aquatic Heteroptera and Coleoptera in standing water, there are very few comparisons of their performance in different types of habitat. In this study, we evaluated and compared the efficiency and selectivity of three sampling methods: hand netting, bottle traps baited with canned tuna and bottle traps baited with canned cat food. The methods were compared over the period 2010-2012 in two different habitats (temporarily flooded areas and canals) in the Nature Park Kopački rit, a floodplain on the banks of the River Danube. The results show that the effectiveness of the method differed in the two habitats. Overall, hand netting was the most successful method, mainly in canals. Tuna fish bait was more efficient than the commonly used cat food, especially for large and highly mobile species of Dytiscidae. These findings indicate that knowing the type of habitat and the habitat preferences of aquatic insects and their activity it is possible to predict which of these methods are the best for estimating species richness.
\end{abstract}

\section{INTRODUCTION}

Aquatic bugs and beetles (Heteroptera and Coleoptera) are groups of freshwater macroinvertebrates that includes predatory and scavenger species. They occur in almost any type of freshwater system, such as wetlands, snow pools, lakes, streams, rivers, wet rock surfaces, puddles and groundwater aquifers often with a high species richness (Franciscolo, 1979; Nilsson \& Holmen, 1995; Balke, 2005; Ribera et al., 2007). Factors that positively influence their species richness are water permanence, rich vegetation and absence of shading by trees (Nilsson \& Svensson, 1994; Nilsson \& Holmen, 1995; Batzer \& Wissinger, 1996; Lundkvist et al., 2001; Rundle et al., 2002; Bouchard, 2004; Schäfer et al., 2006). This makes them good bioindicators of habitat quality and recently they have been used for selecting habitats for conservation (Foster, 1987; Sánchez-Fernández et al., 2006; Lock et al., 2013). Large dytiscids and heteropterans are often top predators in fishless aquatic habitats. Dytiscids range in size from 1-50 $\mathrm{mm}$, and are predators both as larvae and adults (Ribera et al., 2007). Dytiscids are excellent swimmers (Nilsson, 1996) that capture their prey while actively swimming (Ribera et al., 1997). Hydrophiloidea are poor swimmers compared to most species of hydradephagan water beetles (Hansen, 1987).

The most commonly used method for sampling aquatic insects in standing waters is hand netting, which includes simply sweeping the habitat with a hand net for a given period of time (Nilsson \& Svensson, 1995; Boukal et al., 2007). Hand netting provides good information about species richness and community composition and is quick and cheap (García-Criado \& Trigal, 2005; Florencio et al., 2012). In addition, various traps are used for collecting mobile swimming taxa of aquatic insects (Nilsson et al., 1994; Lundkvist et al., 2001; Boukal et al., 2007), with or without baits. The most commonly used baits are chicken, beef liver and cat food, and Koese \& Cuppen (2006) report that cat food is the best bait. Activity traps constructed from plastic bottles (bottle traps) perform well in a variety of environments such as lakes (Nilsson et al., 1994; Hyvönen \& Nummi, 2000), ponds (Jurado et al., 2008), wetlands (Lundkvist et al., 2001) and channels (Klečka \& Boukal, 2011).

Previous comparisons of these sampling methods indicate that both methods can be used to sample most species as adults and larvae; however, they differ in their efficien- 
cy, as well as the size and taxon of the insects captured (Hilsenhoff, 1987; Jurado et al., 2008; Klečka \& Boukal, 2011). In particular, hand nets are commonly used for quantitative surveys and are more suitable for collecting small and less mobile taxa (Nilsson \& Svensson, 1995; Nilsson \& Söderberg, 1996; Klečka \& Boukal, 2011), whereas bottle traps are better at capturing large and highly mobile species (Lundkvist et al., 2001; Nilsson et al., 1994; Klečka \& Boukal, 2011). In addition, Klečka \& Boukal (2011) emphasise the need for long-term studies using different methods in order to capture the full richness of water beetles in highly diverse aquatic habitats. Likewise, Jurado et al. (2008) also suggest that combining hand netting and bottle traps in heavily vegetated ponds will provide a more complete picture of the species richness. In analysing the results of the comparison of sampling methods, one must be aware of the ecological requirements of the species, which involves taking into consideration the constraints that the habitat impose, especially those associated with the morphology of the insects (Ribera et al., 1997). Nevertheless, comparisons of methods across different types of aquatic habitats are still rare [but see García-Criado \& Trigal (2005) for pond macroinvertebrates and Tolonen \& Hämäläinen (2010) for littoral macroinvertebrates].

In this paper we compare the efficiency of three different sampling methods in two different types of habitat: hand netting $(\mathrm{HN})$, bottle traps with cat food as the bait $(\mathrm{BCF})$ and bottle traps baited with tuna fish (BTF). Our specific aims were to: (1) determine which sampling method is the most efficient in each of the two habitats, (2) determine size selectivity of the different sampling methods and (3) determine the efficiency of a new type of bait (canned fish) for sampling aquatic insects. Based on previous studies, we hypothesized that the effectiveness of the methods would depend on the type of habitat. Furthermore, we assumed that the methods would be size selective and that of the two baits used, canned tuna fish would be the most effective.

\section{MATERIALS AND METHODS}

\section{Study area}

Nature Park Kopački rit is located in eastern Croatia $\left(45^{\circ} 34^{\prime}\right.$ latitude, $16^{\circ} 24^{\prime}$ longitude), near the town of Osijek (Fig. 1). It extends over an area of $100 \mathrm{~km}^{2}$ and is one of the largest fluvial floodplains in Europe listed in the Ramsar Convention. The wider area of Kopački rit contains a variety of aquatic habitats that can be divided into three basic types: flooded areas, canals and ponds. Their appearance and structure depend on the specific water regimes in the Danube and Drava rivers.

The flooded areas are flowing or semi-flowing types of habitat, which directly depend on the water level and hydrological connectivity with the parent river. If the water level of the Danube is high, a large part of the floodplain area is flooded, creating a mosaic of permanent and temporarily flooded habitats. Canals are located in the wider area of Kopački rit, which collect water from the wider area of Baranya and spread it within the park. The complex of canals has a lower water flow capacity than the Drava and Danube rivers. The water quality in these habitats importantly depends on the proximity of agricultural fields.

Due to a great variety of aquatic microhabitats, Kopački rit includes numerous suitable habitats for aquatic insects. The

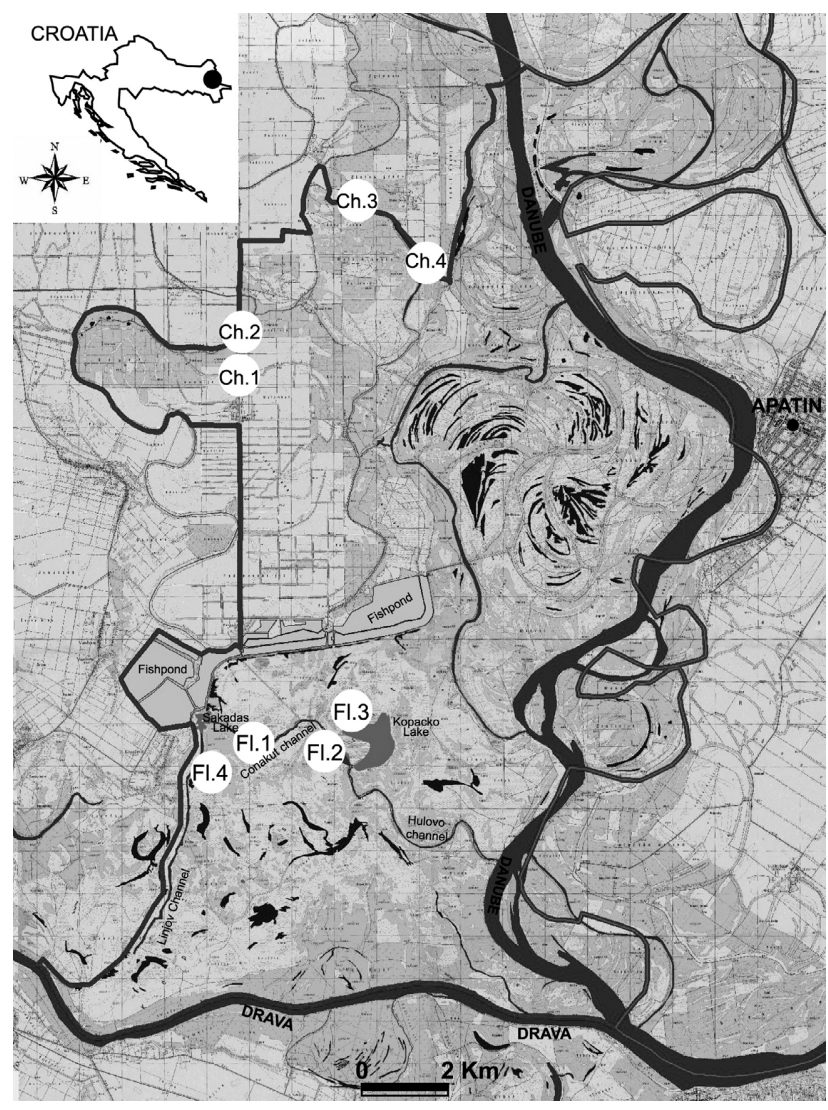

Fig. 1. Map of the study area showing the locations of the eight sites sampled (circles) in the Nature Park Kopački rit, Croatia (Canals: 1 - Podunavlje I, 2 - Podunavlje II, 3 - Čarna I, 4 - Čarna II; Periodically flooded areas: 5 - Čonakut I, 6 - Čonakut II, 7 Kopačko Lake, 8 - Novi Canal).

changes in water levels and duration of the hydroperiod are the most important factors influencing the structure of the aquatic insect fauna (Schneider \& Frost, 1996; Turić et al., 2015) because newly flooded wetlands are often nutrient-rich and may provide suitable feeding and reproduction possibilities for aquatic insects (Nilsson \& Holmen, 1995; Batzer \& Wissinger, 1996; Schneider, 1999; Larson et al., 2000; Wilcox, 2001). Research on aquatic insects in the Kopački rit area has increased during the last ten years. Recent studies on aquatic bugs and beetles (Heteroptera and Coleoptera) in this area have recorded 15 families, 40 genera and 71 species, and indicate that there is a considerable difference between the recorded species richness (71 species) and the number that is estimated could be collected with reasonable effort (between 83 and 111) (Turić et al., 2012). A full list of the species of aquatic insects in this area has yet to be published.

\section{Sampling}

The research was conducted in two types of habitat (flooded areas and canals) and sampling was carried out at eight sampling sites once a month over three years, from 2010 to 2012, in the period from April to October. Four sampling sites were canals situated in the forest area in the wider area of the Nature Park, which flow through the agricultural basin (Fig. 1). The other four sampling sites were located in periodically flooded areas within the most valuable section of the park, which has been given Special Zoological Reserve status. A description of each sampling site is provided in Table 1.

We used two sampling methods: a large hand net (mesh size 1 $\mathrm{mm}$ ) and bottle traps with baits. Our hand net was $60 \mathrm{~cm}$ in diameter, with a $3-\mathrm{m}$ long wooden handle. Together with the large 
Table 1. Description of sampling sites.

\begin{tabular}{|c|c|c|c|}
\hline Site & Site code & Habitat & Coordinates \\
\hline Podunavlje I & Ch Pod I & Canal & $45^{\circ} 41^{\prime} \mathrm{N} ; 18^{\circ} 48^{\prime} 49^{\prime \prime} \mathrm{E}$ \\
\hline Podunavlje II & Ch Pod II & Canal & $45^{\circ} 41^{\prime} 24^{\prime \prime} \mathrm{N} ; 18^{\circ} 48^{\prime} 49^{\prime \prime} \mathrm{E}$ \\
\hline Čarna I & Ch Car I & Canal & $45^{\circ} 43^{\prime} 22^{\prime \prime} \mathrm{N} ; 18^{\circ} 50^{\prime} 28^{\prime \prime} \mathrm{E}$ \\
\hline Čarna II & Ch Car II & Canal & $45^{\circ} 42^{\prime} 24^{\prime \prime} \mathrm{N} ; 18^{\circ} 52^{\prime} 14^{\prime \prime} \mathrm{E}$ \\
\hline Čonakut I & FI Con I & Flooded area & $45^{\circ} 36^{\prime} 34^{\prime \prime} \mathrm{N} ; 18^{\circ} 48^{\prime} 25^{\prime \prime} \mathrm{E}$ \\
\hline Čonakut II & FI Con II & Flooded area & $45^{\circ} 36^{\prime} 16^{\prime \prime} \mathrm{N} ; 18^{\circ} 48^{\prime} 60^{\prime \prime} \mathrm{E}$ \\
\hline Kopačko Lake & FI KJ & Flooded area & $45^{\circ} 36^{\prime} 27^{\prime \prime} \mathrm{N} ; 18^{\circ} 50^{\prime} 19^{\prime \prime} \mathrm{E}$ \\
\hline Novi Canal & $\mathrm{FINC}$ & Flooded area & $45^{\circ} 36^{\prime} 23^{\prime \prime} \mathrm{N} ; 18^{\circ} 48^{\prime} 5^{\prime \prime} \mathrm{E}$ \\
\hline
\end{tabular}

hand net a strainer (mesh size $0.5 \mathrm{~mm}$ ) was used for collecting the smallest species along the shore of the water habitat. Each sampling session consisted of five sweeps just under the surface of the water at each site, including subaquatic and aquatic vegetation in the littoral zone, so that an area of $3 \mathrm{~m}^{2}$ was sampled each time. On each occasion, the sampling time was $1 \mathrm{~h}$, including time spent sweeping and removing adult insects from the sample so that the different vegetation units, substrates and open water areas were similarly sampled.

In addition to sampling by hand net, two bottle traps with bait (one with tinned tuna fish and other with cat food) were placed at each site on each sampling occasion (Koese \& Cuppen, 2006). Traps were made from two $1.5 \mathrm{~L}$ plastic bottles with an inner neck diameter of $21 \mathrm{~mm}$. The bottom of one bottle was cut off and the top of the other was placed upside down in first bottle, so the trap has funnel entrance and exit with a cap. After the traps were slowly removed from the water, the cap was removed above a strainer to enable the collection of all the specimens caught. Traps were placed along the water's edge in different microhabitats and immersed in water so that about $4 / 5$ of their volume was filled with water and the rest with air and protruded above the surface. The minimum distance between neighbouring traps was $3 \mathrm{~m}$. Considering the high water temperatures and competition between the trapped species (Boukal et al., 2007), traps were set in the afternoon and picked up during the next day, after a period of $20 \mathrm{~h}$ in the water (one trapping night). In total, 336 traps were set during the field survey.

We compared the efficiency of the methods used based on the samples collected, because we collected the same number of samples, at the same sampling sites over the same period of time. The sampling effort for each method was equal because we took samples at eight sampling sites once a month for seven months during three years. Thus, we had 168 samples collected by each method, which makes a total of 504 samples. Captured specimens were preserved in $70 \%$ ethanol, except for large specimens that we could be immediately identified after sampling, especially specimens of Graphoderus bilineatus De Geer, which were released after identification in the field. Only adult aquatic insects were collected; these were identified in the laboratory using the keys and descriptions of Macan (1976), Nilsson (1996), Csabai (2000) and Csabai et al. (2002). All species are stored in the Entomological collection of the Department of Biology at Josip Juraj Strossmayer University in Osijek.

\section{Data analyses}

To estimate and compare the species richness recorded by the different sampling methods, we computed sample-based rarefaction curves (accumulation curves) for each method and for the pooled methods in order to estimate the species richness obtained by all the methods combined. The observed species richness (Sobs) was compared with two commonly used estimators of species richness ICE (Incidence-based Coverage Estimator) and Chao2 to assess the sampling completeness of each method and all methods combined. Rarefaction curves with 100 randomisa- tions without replacement and 95\% confidence intervals were calculated using procedures and formulas implemented in the EstimateS 8.2.0 software (Colwell et al., 2004). Differences in the species richness and Shannon diversity index obtained using each method in two types of habitat were also tested by means of a generalized linear model (GLM) with Poisson distribution and log-link function, considering two categorical factors (method and habitat type). Tests for the significance of the effects in the model were performed using Wald statistics.

Finally, to evaluate the relative effect of the various sampling methods and habitats on the composition of aquatic insect assemblages, we performed a CCA (Canonical Correspondence Analysis) using CANOCO 4.5 (Ter Braak \& Smilauer, 2002). For the CCA, we used only species for which at least 5 individuals were collected; thus, 61 out of 102 species were included in the analysis. For all our analyses, we used all the samples as our input data, where one sample represented all individuals collected by one method at one sampling site on one date.

To demonstrate the body size selectivity of the different methods, we compared the body size (mean length in $\mathrm{mm}$ ) of collected species among the methods using a generalized linear model (GLM) in which body size was treated as a continuous dependent variable in the analyses. The body size of collected species was obtained from the identification keys of Csabai (2000), Csabai et al. (2002), Nilsson (1996) and Macan (1976). Generalized linear models and Wald statistics were calculated using STATISTICA 10 package.

\section{RESULTS}

\section{Abundance and species richness}

In total, 504 samples and 8082 adult individuals of 102 species of aquatic insects were collected using the three sampling methods. Of the 102 identified species, 77 belong to the order Coleoptera [suborder Adephaga (49): Dytiscidae 40, Haliplidae 6, Noteridae 2 and Gyrinidae 1; suborder Polyphaga (28): Spercheidae 1, Hydrochidae 1, Hydrophilidae 26] and 25 to the order Hemiptera (Suborder Heteroptera; Gerromorpha, Nepomorpha). The most abundant species were Plea minutissima (41.9\%), Ilyocoris cimicoides (10.3\%), Laccophilus poecilus (7.5\%) and $\mathrm{Hy}$ grotus versicolor (4.7\%) (Table 2). Most of the individuals were captured using HN [7051 (87.2\%)]. Bottle traps with bait captured 1031 individuals in total $(12.7 \%)$, of which $30.16 \%$ were captured by BCF and $69.8 \%$ by BTF traps.

\section{Comparative analysis of sampling methods}

Out of the 102 species recorded, only 25 were captured by all three sampling methods, while 53 species were captured by only one, indicating that the sampling methods used differed in the species composition of their captures. Plea minutissima was the most abundant species captured 
Table 2. The list of species, their sizes and number of individuals caught using three sampling methods from April to October over a period of three years. Sampling method: HN - hand netting, BCF - bottle traps baited with canned cat food, BTF - bottle traps baited with canned tuna fish. Size: $\mathrm{S}-$ small $0.2-0.5 \mathrm{~cm}, \mathrm{M}-$ medium $0.5-1.5 \mathrm{~cm}, \mathrm{~L}-$ large $<1.5 \mathrm{~cm}$ ).

\begin{tabular}{|c|c|c|c|c|c|c|c|c|c|c|c|}
\hline \multirow{3}{*}{$\begin{array}{l}\text { Species (abbreviation) } \\
\text { Nepa cinerea Linnaeus, } 1758 \text { (Nepa cin) }\end{array}$} & \multicolumn{4}{|c|}{$\begin{array}{c}\text { Sampling } \\
\text { method }\end{array}$} & \multirow[t]{2}{*}{$\Sigma$} & \multirow[t]{2}{*}{ Species (abbreviation) } & \multicolumn{5}{|c|}{$\begin{array}{c}\text { Sampling } \\
\text { Size } \quad \text { method } \quad \text {. }\end{array}$} \\
\hline & \multicolumn{4}{|c|}{ HN BCFBTF } & & & \multicolumn{5}{|c|}{ Size $\frac{\text { method }}{\text { HN BCF BTF }} \Sigma$} \\
\hline & $\mathrm{L}$ & 14 & 0 & 1 & 15 & Ilybius fulinginosus Fabricius, 1792 (Ilyb ful) & M & 1 & 0 & 0 & \\
\hline Ranatra linearis Linnaeus, 1758 (Rana lin) & L & 42 & 3 & 6 & 51 & Colymbetes fuscus Linnaeus, 1758 (Coly fus) & M & 0 & 3 & 3 & 6 \\
\hline Hesperocorixa linnaei Fieber, 1848 (Hesp linn) & M & 2 & 0 & 0 & 2 & Rhantus bistriatus Bergsträsser, 1778 (Rhan bis) & M & 1 & 4 & 0 & 5 \\
\hline Hesperocorixa sahlbergi Fieber, 1848 (Hesp sah) & M & 1 & 0 & 0 & 1 & Rhantus exsoletus Forster, 1771 (Rhan exo) & M & 1 & 1 & 12 & 14 \\
\hline Sigara distincta Fieber, 1848 (Siga dis) & M & 2 & 0 & 0 & 2 & Rhantus latitans Sharp, 1882 (Rhan lat) & M & 6 & 7 & 13 & 26 \\
\hline Sigara dorsalis Leach, 1817 (Siga dor) & M & 134 & 3 & 2 & 139 & Rhantus notaticollis Aubé, 1837 (Rhan not) & M & 0 & 1 & & \\
\hline Sigara lateralis Leach, 1817 ( & M & 7 & 0 & 1 & 8 & Rhantus suturalis MacLeay, 1825 (Rha & M & 3 & 7 & 9 & 19 \\
\hline Sigara nigrolineata Fieber, 1848 (Siga nig) & M & 60 & 0 & 1 & 61 & Acilius canaliculatus Nicolai, 1822 (Acil can) & $\mathrm{L}$ & 0 & 0 & 1 & \\
\hline Sigara semistriata Fieber, 1848 (Siga sem) & M & 21 & 0 & 0 & 21 & Acilius sulcatus Linnaeus, 1758 (Acil sul) & $\mathrm{L}$ & 0 & 1 & 9 & 10 \\
\hline Sigara striata Linnaeus, 1758 (Siga stri) & M & 30 & 1 & 0 & 31 & Graphoderus austriacus Strum, 1834 (Grap aus) & M & 1 & 0 & 2 & 3 \\
\hline Sigara falleni Fieber, 1848 (Siga fal) & M & 4 & 0 & 0 & 4 & & M & 7 & 5 & 10 & 22 \\
\hline Cymatia coleoptrata Fabric & $\mathrm{s}$ & 3 & 0 & 0 & 3 & Graphoderus cinereus Linnaeus, 1758 & M & 1 & 5 & 29 & 35 \\
\hline Iyocoris cimicoides L & M & 731 & 25 & 83 & 839 & Cybister lateralimarginalis De Geer, 1 & L & 21 & 43 & & \\
\hline Notonecta $v$ & M & 3 & 0 & 0 & 3 & Dytiscus circumcinctus Ahrens, 1 & $\mathrm{~L}$ & 0 & 1 & & 1 \\
\hline ta $\mathrm{F}$ & M & 7 & 0 & 1 & 8 & Dytiscu & $\mathrm{L}$ & 0 & & & \\
\hline Voton & M & 18 & 5 & 0 & 23 & Dytiscus marginalis Linn & $\mathrm{L}$ & 0 & & & \\
\hline tissim & $\mathrm{s}$ & 3344 & 5 & 45 & & Dytiscus semisulcatus $\mathrm{O}$ & $\mathrm{L}$ & 0 & 0 & & \\
\hline Mesovelia furcata Mulsant & $\mathrm{s}$ & 40 & 0 & 0 & 40 & Hydaticus grammicus Germar, & M & 6 & 4 & 4 & \\
\hline tra aracilie & M & 4 & 0 & 0 & 4 & Hydatice & M & 1 & 1 & 1 & \\
\hline & M & 45 & 0 & 0 & 45 & yda tra) & $M$ & 5 & 15 & 15 & 35 \\
\hline Aquaril & M & 82 & 0 & 0 & 82 & Noterus clavicornis De Geer, 1774 (Not & $\mathrm{s}$ & 47 & 0 & 2 & 49 \\
\hline Gerris lacustris Linné, 1 & M & 305 & 0 & 0 & 305 & Noterus crassicornis O.F. Müller, 1776 (Not cras) & $\mathrm{s}$ & 38 & 2 & 3 & 43 \\
\hline Gerris & M & 38 & 0 & 0 & 38 & Gyrinus substria & M & 2 & 0 & 0 & 2 \\
\hline & $s$ & 3 & 0 & 0 & 3 & Spercheus ema & M & 51 & 1 & 0 & 52 \\
\hline Micr & $\mathrm{s}$ & 15 & 0 & 0 & 15 & & $\mathrm{~s}$ & 2 & 0 & 0 & \\
\hline & S & 86 & 0 & 1 & 87 & & $S$ & 0 & 1 & & 1 \\
\hline & $S$ & 3 & 0 & 0 & 3 & Helop & $S$ & 2 & 0 & & \\
\hline & $s$ & 8 & 0 & 0 & 8 & Helop & $\mathrm{s}$ & 1 & 0 & & 1 \\
\hline & $\mathrm{s}$ & 23 & 0 & 1 & 24 & $\mathrm{Cc}$ & $\mathrm{s}$ & 1 & & & 1 \\
\hline var) & $S$ & 5 & 1 & 0 & 6 & Cercy & M & 1 & 0 & & \\
\hline & $s$ & 42 & 4 & 5 & 51 & & $\mathrm{~s}$ & 1 & 0 & 0 & \\
\hline Copelatus haemorrhoidalis Fabricius, 1787 (Cope hae) & ) $M$ & 0 & 0 & 1 & 1 & & $\mathrm{~s}$ & 16 & 0 & 0 & 16 \\
\hline Bidessus unistriatus Goeze, 1777 (Bide uni) & $s$ & 1 & 0 & 0 & 1 & Anacaena lutescens Stephens, 1 & $\mathrm{~s}$ & 1 & 0 & 0 & 1 \\
\hline Hydroglyphus confusus Klug, 1 & $\mathrm{~s}$ & 7 & 3 & 4 & 14 & Laccobius minutus Linnaeus, 175 & $\mathrm{~s}$ & 9 & 0 & 0 & 9 \\
\hline lydroglyphus geminus Fabricius, 1792 (Hydr gem) & $\mathrm{s}$ & 149 & 11 & 4 & 164 & Enochrus melanocephalus Olivier, 1792 (Enoc mel) & $\mathrm{s}$ & 11 & 0 & 0 & 11 \\
\hline Hydroporus palustris Linnaeus, 1761 (Hydr pal) & s & 6 & 0 & 0 & 6 & Enochrus bicolor Fabricius, 1792 (Enoc bic) & M & 4 & 0 & 0 & 4 \\
\hline & $\mathrm{s}$ & 1 & 0 & 1 & 2 & & M & 4 & 0 & 0 & 4 \\
\hline & $\mathrm{s}$ & 1 & 0 & 0 & 1 & & M & 3 & & 0 & \\
\hline & $S$ & 1 & 0 & 0 & 1 & & M & 31 & & 0 & 31 \\
\hline & $\mathrm{s}$ & 336 & 5 & 44 & 385 & & & 6 & & & \\
\hline & ) $s$ & 20 & 1 & 0 & 21 & & $S$ & 2 & 0 & 0 & 2 \\
\hline & $\mathrm{s}$ & 4 & 0 & 0 & 4 & & M & 15 & 2 & 0 & 17 \\
\hline & $s$ & 5 & 3 & 2 & 0 & & M & 261 & 0 & & \\
\hline & $\mathrm{s}$ & & 1 & 2 & 14 & & M & 10 & 2 & 0 & 12 \\
\hline Laccophilus hyalinus De Geer, 1774 (Lacc hya) & $\mathrm{s}$ & 10 & 0 & 0 & 10 & Hydrochara caraboides Linnaeus, 1758 (Hydr car) & L & 7 & 3 & 1 & 11 \\
\hline Laccophilus minutus Linnaeus, 1758 (Lacc min) & $\mathrm{s}$ & 121 & 9 & 88 & 218 & Hydrophilus aterrimus Eschscholtz, 1822 (Hydr ate) & $\mathrm{L}$ & 1 & 1 & 0 & 2 \\
\hline Laccophilus poecilus Klug, 1834 (Lacc poe) & $\mathrm{s}$ & 456 & 69 & 84 & 609 & Hydrophilus piceus Linnaeus, 1792 (Hydr pic) & $\mathrm{L}$ & 19 & 0 & 3 & 22 \\
\hline Agabus undulatus Schrank, 1776 (Agab und) & M & 0 & 0 & 1 & 1 & Limnoxenus niger Zschach, 1788 (Limn nig) & M & 5 & 5 & 1 & \\
\hline Agabus affinis Paykull, 1798 (Agab aff) & M & 0 & 1 & 0 & 1 & Berosus geminus Reiche \& Saulcy, 1856 (Bero gem) & M & 16 & 0 & 0 & \\
\hline Ilybius ater De Geer, 1774 (Ilyb ate) & M & 0 & 1 & 0 & 1 & Berosus signaticolis Charpentier, 1825 (Bero sig) & M & 116 & 1 & 0 & \\
\hline & M & & 41 & & & Berosus frontifoveatus Kuwert, 1888 (Bero fro) & & & & & \\
\hline
\end{tabular}

by $\mathrm{HN}(47.4 \%)$, Laccophilus poecilus $(22.2 \%)$ by BCF and Cybister lateralimarginalis De Geer (23.6\%) by BTF. If we examine the effectiveness of each method separately, the sample-based accumulation curves indicate that 89 species were collected by HN, 43 by BCF and 44 by BTF (Figs $2 \mathrm{a}-\mathrm{b})$. The accumulation curves for the different methods all displayed upward trends (Fig. 2a). Sample-based rarefaction curves were also used to compare the observed species richness (Sobs) with those estimated. We used two estimators, Chao2 and ICE, known to be highly effective for freshwater invertebrate assemblages (Foggo et al., 2003). On the one hand, using BTF, there were smaller differences between the Sobs and species richness estimated by ICE and Chao2 (Fig. 2b). Comparisons of ICE to Sobs suggest little difference between the two baits, only Chao2 is different because BCF recorded fewer species than estimated. However, the accumulation curve for all three methods combined was close to plateauing and the estima- 


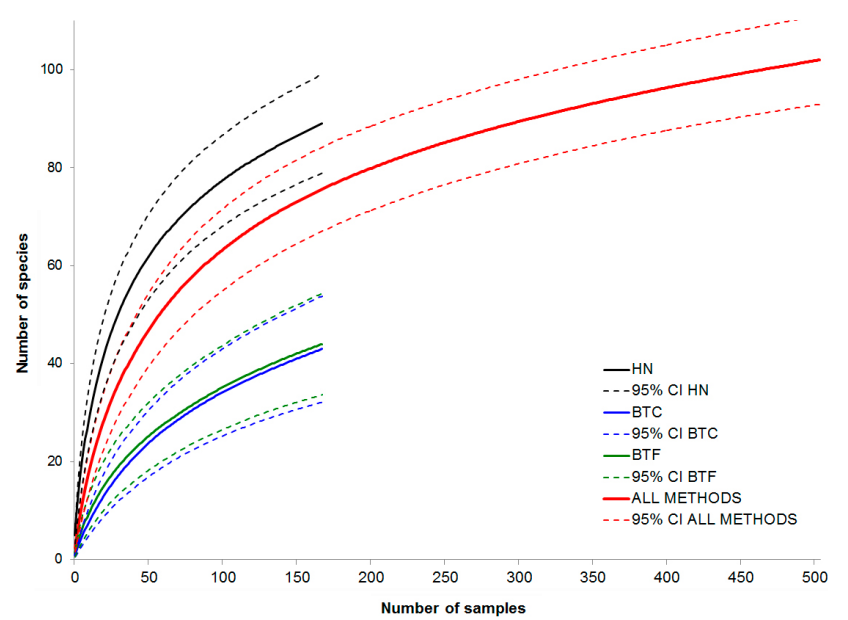

Fig. 2a. Comparison of sample-based accumulation curves (mean of 100 randomizations) for each method with $95 \%$ confidence intervals (dashed lines) and for all methods combined (red line) with $95 \%$ confidence interval (red dashed line).

tors used indicated almost complete sampling based on all of the data obtained by the different methods combined.

\section{Comparison of the sampling methods in the different habitats}

Our research was conducted in two different habitats (canals and flooded areas) and all three sampling methods were used in each habitat in order to compare their effectiveness. In the canals, we collected a total of 96 species, while in the periodically flooded area 65 species. We found significant differences in the efficiency of the methods used in the two habitats.

A GLM analysis revealed significant differences in species richness and Shannon diversity index per sample both between methods and between habitats (Table 3). Interactions between factors were significant when the dependent variable was species richness, habitat type and a combination of these two variables. HN was by far the most effective method for collecting insects in both canals and flooded areas (Fig. 3). In canals, BTF was more effective than $\mathrm{BCF}$, while they were equally effective in flooded areas. In the periodically flooded areas, where the abundance of individuals per sample was much lower due to it being a temporary habitat, differences between the methods were less pronounced; however, despite this, $\mathrm{HN}$ was still the most effective method.

To evaluate the composition of aquatic insect assemblages in relation to the sampling methods and habitats, we performed a CCA analysis (Fig. 4). The CCA confirmed that the sampling methods and habitats both influence the composition of aquatic insect assemblages recorded (a Monte Carlo test for significance of all canonical axes: $\mathrm{F}=7.105$, $\mathrm{P}=0.0001$ ). The first two CCA axes explained $70.3 \%$ of the variance, as follows: $40.5 \%$ was explained by the first axis, which was mainly correlated with the sampling method, and $29.8 \%$ was explained by the second axis, which was best related to habitat (Table 4, Fig. 4). The amount of the total variation that we can explain by habitat and method was $76.3 \%$ (Table 4 ).
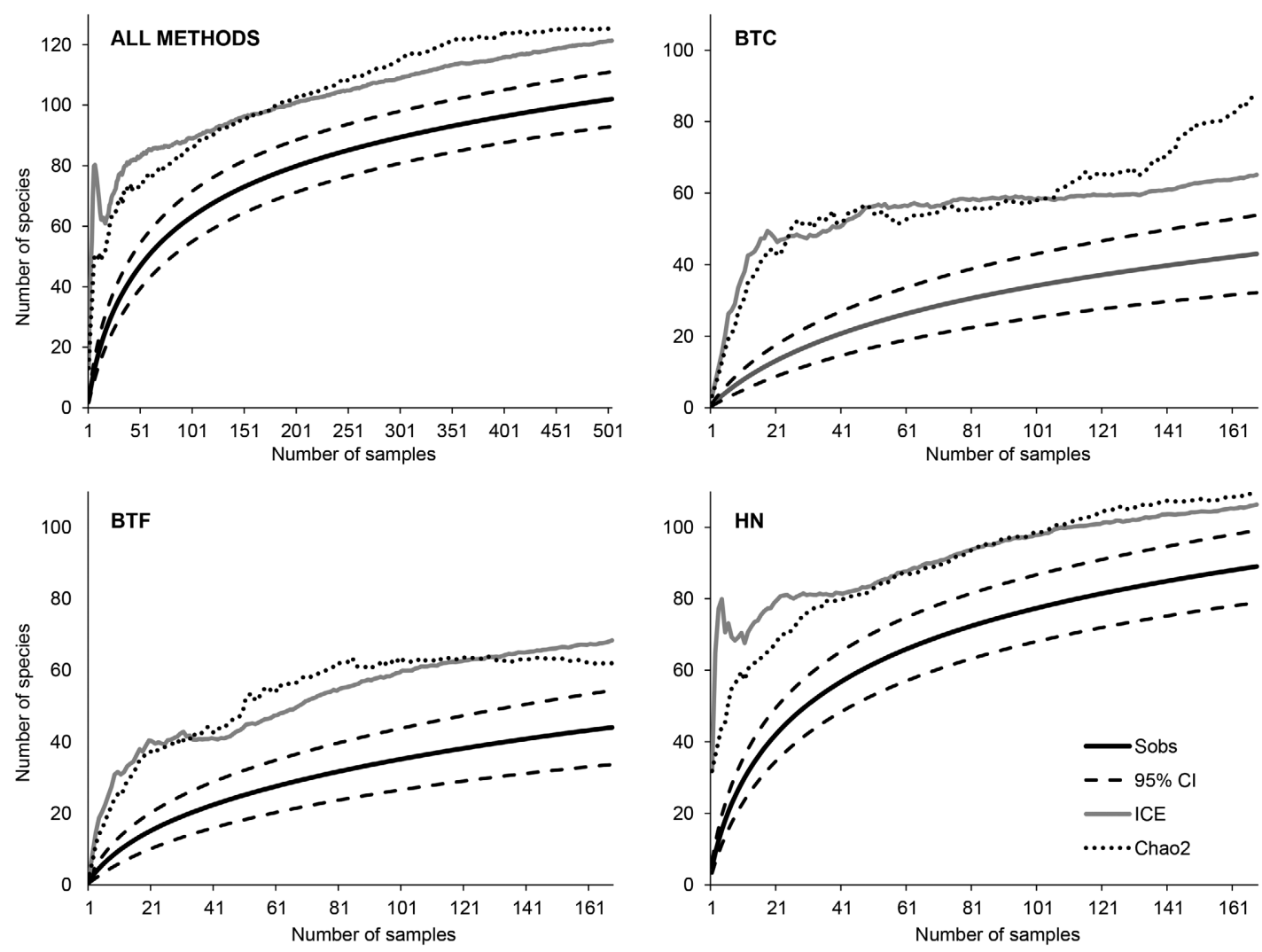

Fig. 2b. Randomized sample-based rarefaction curves for the three sampling methods and all methods combined in comparison with two nonparametric estimators of species richness (Chao2 and ICE - Incidence Coverage-based Estimator). Sobs = observed species richness with $95 \%$ confidence intervals $(95 \% \mathrm{Cl})$. 

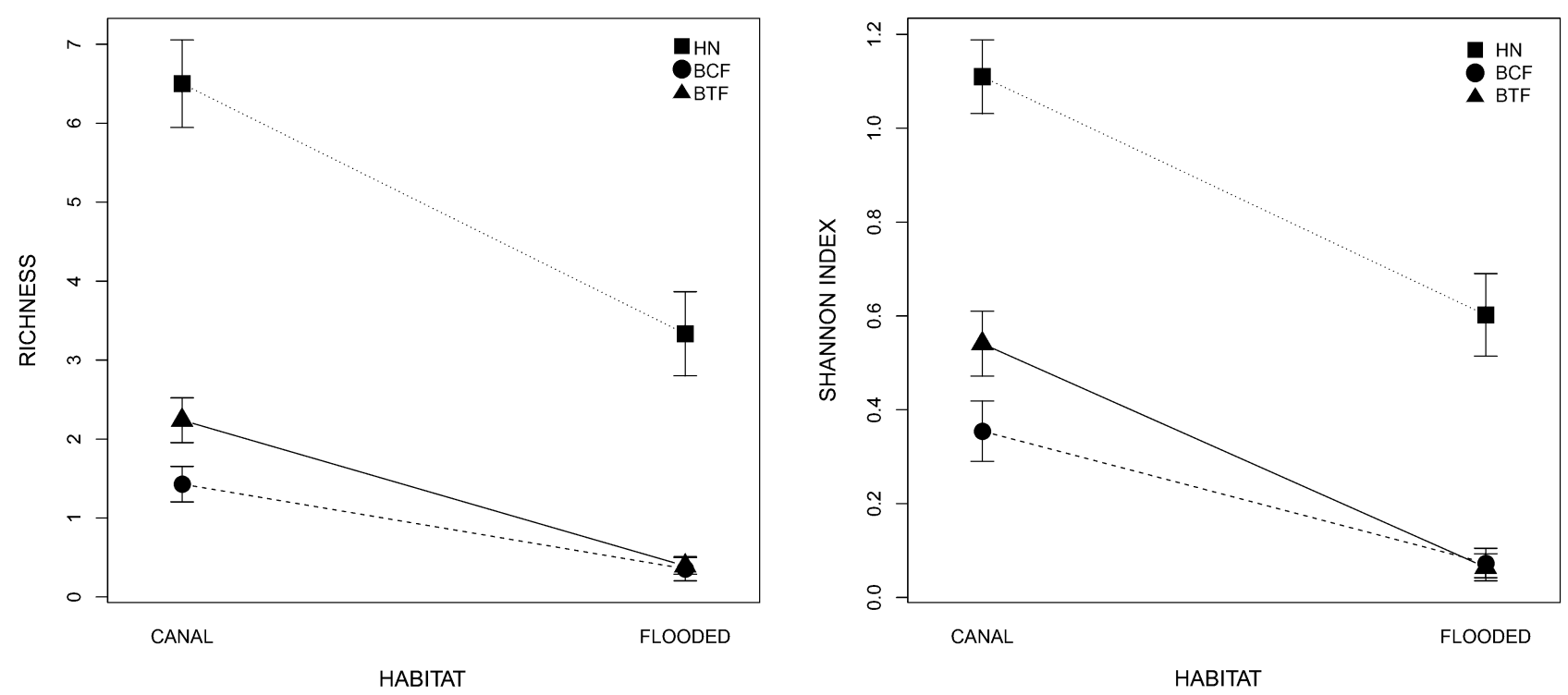

Fig. 3. Results of GLM analysis showing differences in the species richness (number of species) and Shannon diversity index per sample obtained using different sampling methods in two different habitats in the Nature Park Kopački rit. Values are means \pm standard errors.

Canals and flooded areas had specific aquatic insect faunas. The correlation between species composition with habitat and sampling method revealed that each method yielded a different set of species. More species of Heteroptera and Hydrophiloidae were collected using HN, irrespective of the habitat. HN was also the most effective method for collecting Haliplidae, especially in canals, where all 6 species were collected. Only for some Dytiscide, was BTF and BCF more effective than HN in canals (Fig. 4).

Size of the insects collected depended on the sampling method. The difference in the body size of species that were caught by $\mathrm{HN}$ and bottle traps with bait was highly significant (GLM; $F=4.088$, d.f. $=2, \mathrm{P}=0.018$ ) (Fig. 5). More medium and large species of Dytiscidae were collected using BTF and BCF, and more small species using HN.

\section{DISCUSSION}

The wide range of different waterbodies in floodplains, from open water to densely vegetated water, makes them excellent environments for testing the effectiveness of sampling methods for evaluating aquatic insect richness and diversity. A rigorous sampling method is needed in order to avoid underestimating biodiversity, especially in wetland habitats (Becerra Jurado et al., 2008). In our study, we compared the efficiency and selectivity of three sampling methods (HN, BCF and BTF) in two different habitats based on the results of three years of sampling. We tested the efficiency of tuna fish as a bait, which has

Table 3. Tests for the significance of the effects (sampling method and habitat). GLM with Poisson distribution and log-link function was used. The significant $P$-values are in bold.

\begin{tabular}{|c|c|c|c|c|c|c|}
\hline & \multicolumn{3}{|c|}{ Richness } & \multicolumn{3}{|c|}{ Shannon } \\
\hline & DF & Wald stat. & $\mathrm{P}$ & DF & Wald stat. & $\mathrm{P}$ \\
\hline Sampling method & 2 & 489.0 & $<0.001$ & 2 & 73.7 & $<0.001$ \\
\hline Habitat & 1 & 174.1 & $<0.001$ & 1 & 42.9 & $<0.001$ \\
\hline Sampling method*habitat & 2 & 35.2 & $<0.001$ & 2 & 12.3 & $<0.002$ \\
\hline
\end{tabular}

not been used previously as bait in bottle traps. Our results reveal that tuna fish is more efficient than the commonly used cat food when the sampling interval is $\pm 20 \mathrm{~h}$, especially for collecting large species of dytiscid. We also confirmed that habitat has a major effect on the effectiveness of the method, as HN was the most effective, primarily in canals with dense vegetation. It yielded the highest number of species (89 out of 102 collected in total). Previous comparative studies, (Klečka \& Boukal, 2011; Florencio et al., 2012) report similar findings for netting and activity traps.

Furthermore, we compared methods based on species richness using accumulation curves. As suspected, the hand netting and activity traps caught different proportions of the aquatic insects. The difference in the numbers of swimming and non-swimming taxa was most pronounced in the catch of the hand net. Our results suggest that hand netting underestimated the number of actively mobile taxa and the higher percentage of taxa collected using traps with different baits were similar. Furthermore, Becerra Jurado et al. (2008) report that a combination of pond netting and activity traps yields a more complete estimate of taxon richness.

Twelve of the remaining 13 species that were not sampled using HN belong to the Dytiscidae. In general, only dyitiscids were sampled more effectively using bottle traps (of the 40 species collected, only seven were caught exclusively using $\mathrm{HN}$ ). For the Hydrophilidae, HN was more effective than bottle traps in both habitats and especially in flooded areas. This is not surprising because these species usually reside in places with dense aquatic vegetation and are poor swimmers, which crawl more than swim (Nilsson, 1996).

There are two ways of optimizing the use of activity traps in aquatic biodiversity studies: use of attractants and trapping duration. It is reported that the number of taxa and individuals captured increases with use of baits and a longer trapping duration of $48 \mathrm{~h}$ (but not longer) (Verdonschot, 2010). Moreover, in our study canned tuna fish 


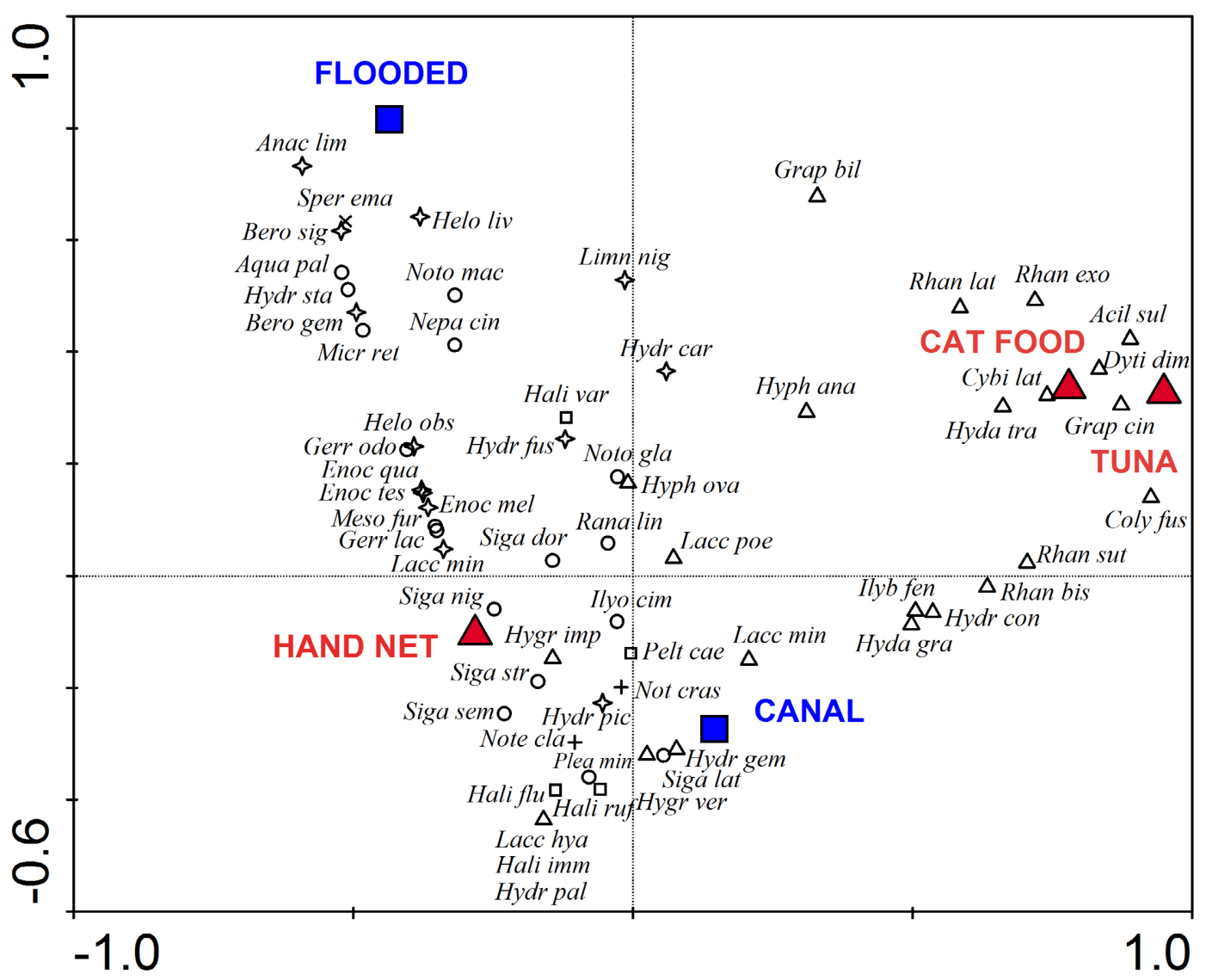

Fig. 4. Ordination diagram of the first two axes of a Cannonical Correspondance analysis (CCA), showing the effect of sampling method and habitat on aquatic insect assemblages in the Nature Park Kopački rit. For abbreviations see Table 2. Different symbols denote different taxonomic groups of aquatic insects ( $\circ$ Heteroptera; $\square$ Haliplidae; + Noteridae; $\Delta$ Dytiscidae; $x$ Spercheidae; $\diamond$ Hydrophilidae).

was generally more effective as a bait than cat food after \pm $20 \mathrm{~h}$, based on the differences in the species richness and Shannon diversity index. A previous study suggested that cat food is a better bait than chicken liver (Koese \& Cuppen, 2006); however, our results demonstrate that canned tuna fish should be the first choice of bait. Differences in

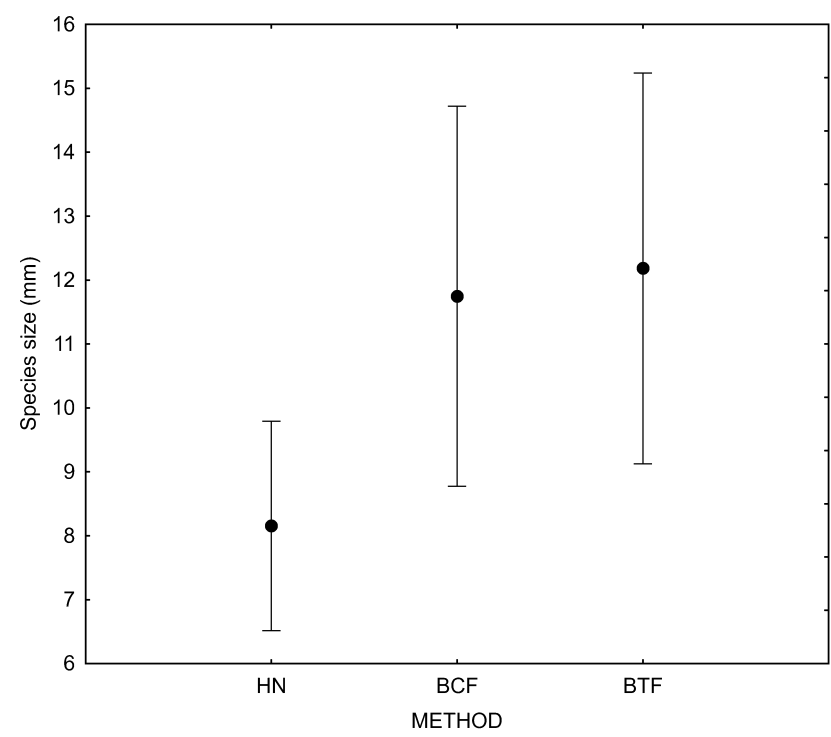

Fig. 5. Average size of the insects caught by the three sampling methods (GLM with Normal distribution and log-link function). Vertical bars denote $95 \%$ confidence intervals. the chemical cues released by different baits (tuna fish and cat food) could cause differences in efficiency. Nevertheless, in future studies other more common species of fish of lower conservation concern should be considered as bait instead of tuna fish, however, their effectiveness needs to be tested.

We are aware that we used only two methods from a large set of well-known methods that are used to survey aquatic insects, but using several methods, particularly hand netting and bottle traps is suggested to result in a more complete species richness for a specific area (Hilsenhoff, 1987; Becerra Jurado et al., 2008; Klečka \& Boukal, 2011). Our results reiterate previous findings that using only bottle traps may not always produce representative data for all aquatic insect groups (Turner \& Trexler, 1997). Bottle traps catch insects that actively move in the water; consequently, the more sluggish and immobile insects may be under-represented (Thomas et al., 2009). In addition, using several combinations of methods is necessary for long-term studies measuring diversity in species-rich freshwater habitats (Klečka \& Boukal, 2011).

\section{Performance of methods in different habitats}

HN sampled the most species in the canals (80 out of 89). This finding was expected because species captured in canals are considered to be adapted to crawl among dense vegetation or detritus (Nilsson, 1996), and there is a rich 
Table 4. Eigenvalues and percentage of the variability accounted for by the variables measured along the first four axes of the Cannonical Correspondance analysis (CCA). * The sum of the unconstrained eigenvalues represents the total inertia.

\begin{tabular}{|c|c|c|c|c|c|}
\hline CCAAxes & 1 & 2 & 3 & 4 & Total inertia \\
\hline Eigenvalues & 0.405 & 0.298 & 0.060 & 0.480 & 9.284 \\
\hline Species environment correlations & 0.837 & 0.831 & 0.489 & 0.000 & \\
\hline Cumulative $\%$ of variation (species data) & 4.4 & 7.6 & 8.2 & 13.4 & \\
\hline Cumulative $\%$ of variation (species-environment relation) & 53.1 & 92.1 & 100.0 & 100.0 & \\
\hline Sum of all eigenvalues * & & & & & 9.284 \\
\hline Sum of all canonical eigenvalues & & & & & 0.763 \\
\hline
\end{tabular}

submerged vegetation along the banks of these canals. Previous studies demonstrate that the efficiency of hand netting may be less in the heavily vegetated areas, presumably because the vegetation interferes with the free movement of the hand net; thus, the probability of capturing highly mobile species decreases (Becerra Jurado et al., 2008). Contrary to this, our large hand net proved to be very useful because it easily passed through aquatic vegetation and brushed insects off the vegetation. Bottle traps with different baits were equally efficient in the flooded area, however BTF was more efficient in the canals than BCF. Habitat structure, biotic interactions and physicochemical factors can influence macroinvertebrate activity-density patterns (Verdonschot, 2010). Bottle traps catch mainly dytiscid species, i.e. insects that actively move in the water and that are normally the top predators in the trophic web of these ecosystems (Becerra Jurado et al., 2008; Thomas et al., 2009).

A lower number of species was collected in flooded areas than canals. Floodplains are unique habitats where sampling is dependent on the water level, which varies from month to month. Thus, food resources and the ability of species to find food and colonize different habitats changes with the constantly fluctuating water levels and is thus likely to influence the aquatic insect assemblages (Williams, 1996; Fairchild et al., 2003; Turić et al., 2015). In addition, in periodically flooded areas there is no dense vegetation and the absence of shading effects from trees affects the abundance of species and species composition of assemblages (Nilsson \& Svensson, 1994; Nilsson \& Söderberg, 1996; Lundkvist et al., 2001; Rundle et al., 2002; Schäfer et al., 2006).

The species composition depended on the habitat and sampling method. There were remarkable differences in species pools and abundances recorded in canals and flooded areas, most likely due to the highly specific nature of the flooded areas. We confirmed that adults of Heteroptera and Hydrophilidae are more efficiently sampled using a hand net (Ortmann-Ajkai \& Kalman, 2011). Large species of Dytiscidae were under sampled by hand netting, because they were less abundant than small species and are also more efficient at avoiding being caught by hand netting (Klečka \& Boukal, 2011). It is well known that the catches of activity traps better reflect the abundance of mobile aquatic insects, mainly dytiscids, corixids and notonectids (Elmberg et al., 1992; Verdonschot, 2010).

The methods used also differed in size selectivity. In this study, small species were mostly captured using a $\mathrm{HN}$ and medium and large species by the bottle traps, as previously shown by other authors (Hilsenhoff, 1987; Klečka \& Boukal, 2011). In marked contrast, Nilsson \& Söderberg (1996) conclude there is no significant difference in the body size of the species of dytiscids caught using bottle traps and hand netting; however, their samples were collected from different localities in the same area, which might have influenced their results (Klečka \& Boukal, 2011). In this study, we collected samples from each habitat at the same locality using all three methods; therefore, we are confident that these methods are size selective.

The presence of a Red List species of water beetle in the study area (Graphoderus bilineatus) indicates it is necessary to improve the widely used bottle traps and use traps in which the beetles are more likely to survive in habitats that might harbour this or other endangered species. Our contribution to the ongoing debate about different sampling techniques (Nilsson \& Söderberg, 1996; Turner \& Trexler, 1997; Becerra Jurado et al., 2008; Klečka \& Boukal, 2011; Florencio et al., 2012) is the testing of canned tuna fish as a bait in activity traps. Numerous papers report that the efficiency of traps used for collecting water beetles is increased by using bait, the smell of which attracts the beetles. Tuna fish is a good bait because it has a strong odour. The canned tuna fish we used was not of the endangered Bluefin tuna and we assume that bait of other species of fish could be similarly efficient.

\section{REFERENCES}

BALKe M. 2005: Dytiscidae. In Beutel R.G. \& Leschen R. (eds): Handbook of Zoology IV, 38(1), Coleoptera. DeGruyter, Berlin, pp. $90-116$.

Batzer D.P. \& Wissinger S.A. 1996: Ecology of insect communities in nontidal wetlands. - Annu. Rev. Entomol. 41: 75-100.

BouchaRd R.W. 2004: Guide to Aquatic Macroinvertebrates of the Upper Midwest. Water Resources Center, University of Minnesota, St. Paul, 208 pp.

Boukal D.S., Boukal M., Fikáček M., Hájek J., KlečKa J., SkalickÝ S., ŠŤASTNÝ J. \& TrávníčEK D. 2007: Catalogue of water beetles of the Czech Republic (Coleoptera: Sphaeriusidae, Gyrinidae, Haliplidae, Noteridae, Hygrobiidae, Dytiscidae, Helophoridae, Georissidae, Hydrochidae, Spercheidae, Hydrophilidae, Hydraenidae, Scirtidae, Elmidae, Dryopidae, Limnichidae, Heteroceridae, Psephenidae). - Klapalekiana (Suppl.) 43: 289 pp.

Colwell R.K., Mao C.X. \& Chang J. 2004: Interpolating, extrapolating, and comparing incidence-based species accumulation curves. - Ecology 85: 2717-2727.

Csabai Z. 2000: Vizibogarak kishatározója, I. kötet. Vízi természet- és kornyezetvedelem. 15. kötet, Környezetgazdálkodási intézet, Budapest, 267 pp. 
Csabai Z., Gidó Z. \& SzÉL G. 2002: Vízibogarak kishatározója II. [A Guide for the Identification of Water Beetles of Hungary II.] In: Vizi természet- és kornyezetvedelem. 16. kötet. [Water, Nature and Environment Protection. Vol. 16.] Environmental Management Institute, Budapest, 206 pp.

Elmberg J., Nummi P., Pöysä H. \& SJöBerg K. 1992: Do introducing predators affect the reliability of catches in activity traps? - Hydrobiologia 239: 187-193.

Fairchild G.W., Cruz J., Faulds A.M., Short A.E.Z. \& Matta J.F. 2003: Microhabitat and landscape influences on aquatic beetle assemblages in a cluster of temporary and permanent ponds. - J. North Am. Benthol. Soc. 22: 224-240.

Florencio M., Díaz-Paniagua C., Gomez-Mestre I. \& Serrano L. 2012: Sampling macroinvertebrates in a temporary pond: comparing the suitability of two techniques to detect richness, spatial segregation and diel activity. - Hydrobiologia 689: $121-130$

FogGo A., RundLe S.D. \& BiLton D. 2003: The net result: evaluating species richness extrapolation techniques for littoral pond invertebrates. - Freshw. Biol. 48: 1756-1764.

FOSTER G.N. 1987: The use of Coleoptera records in assessing the conservation value of Wetlands. In Luff M. (ed.): The Use of Invertebrate Community Data in Environmental Assessment. University of Newcastle, Newcastle upon Tyne, pp. 8-18.

Franciscolo M.E. 1979: Fauna d'Italia, Vol. XIV: Coleoptera: Haliplidae, Hygrobiidae, Gyrinidae, Dytiscidae. Calderini, Bologna, vi + 804 pp.

García-Criado F. \& Trigal C. 2005: Comparison of several techniques for sampling macroinvertebrates in different habitats of a North Iberian pond. - Hydrobiologia 545: 103-115.

HiLSENHOFF W.L. 1987: Effectiveness of bottle traps for collecting Dytiscidae (Coleoptera). — Coleopt. Bull. 41: 377-380.

HiLSENHOFF W.L. 1991: Comparison of bottle traps with a d-frame net for collecting adults and larvae of Dytiscidae and Hydrophilidae (Coleoptera). - Coleopt. Bull. 45: 143-146.

Hyvönen T. \& Nummi P. 2000: Activity traps and the corer: complementary methods for sampling aquatic invertebrates. $-\mathrm{Hy}$ drobiologia 432: 121-125.

Koese B. \& Cuppen J. 2006: Sampling methods for Graphoderus bilineatus (Coleoptera: Dytiscidae). — Ned. Faun. Meded. 24: $41-48$.

Jurado G.B., Masterson M., Harrington R. \& Kelly-Quinn M. 2008: Evaluation of sampling methods for macroinvertebrate biodiversity estimation in heavily vegetated ponds. - Hydrobiologia 597: 97-107.

KLEČKA J. \& BOUKAL D.S. 2011: Lazy ecologist's guide to water beetle diversity: Which sampling methods are the best? Ecol. Indicat. 11: 500-508.

Larson D.J., Alarie Y. \& Roughley R.E. 2000: Predaceous Diving Beetles (Coleoptera: Dytiscidae) of the Nearctic Region, with Emphasis on the Fauna of Canada and Alaska. NRC Research Press, Ottawa, 982 pp.

Lock K., Adriaens T., van de Meutter F. \& Goethals P. 2013: Effect of water quality on waterbugs (Hemiptera: Gerromorpha \& Nepomorpha) in Flanders (Belgium): results from a large-scale field survey. - Ann. Limnol. / Int. J. Limnol. 49: 121-128.

LundKvist E., Landin J. \& Milberg P. 2001: Diving beetle (Dytiscidae) assemblages along environmental gradients in an agricultural landscape in southeastern Sweden. - Wetlands 21: 48-58.

Macan T.T. 1976: A Revised Key to the British Water Bugs (Hemiptera, Heteroptera) with Nnotes on their Ecology. 2nd ed. Scientific Publication of the Freshwater Biological Association No. 16, 74 pp.
NiLsson A.N. 1996: Aquatic Insects of North Europe, a Taxonomic Handbook. Vol. 1. Apollo Books, Strenstrup, pp. 76-194.

Nilsson A.N. \& Holmen M. 1995: The Aquatic Adephaga (Coleoptera) of Fennoscandia and Denmark. II. Dytiscidae. Fauna Entomologica Scandinavica 32. E.J. Brill, Leiden, New York, Köln, 192 pp.

NilsSon A.N. \& SöDERBERg H. 1996: Abundance and species richness patterns of diving beetles (Coleoptera, Dytiscidae) from exposed and protected sites in 98 northern Swedish lakes. Hydrobiologia 321: 83-88.

NiLsson A.N. \& Svensson B.W. 1994: Dytiscid predators and culicid prey in two boreal snowmelt pools differing in temperature and duration. - Ann. Zool. Fenn. 31: 365-376.

Nilsson A.N. \& Svensson B.W. 1995: Assemblages of dytiscid predators and culicid prey in relation to environmental factors in natural and clear-cut boreal swamp forest pools. - Hydrobiologia 308: 183-196.

Nilsson A.N., Elmberg J. \& Sjoberg K. 1994: Abundance and species richness patterns of predaceous diving beetles (Coleoptera, Dytiscidae) in Swedish lakes. - J. Biogeogr. 21: 197-206.

Ortmann-Ajkai A. \& Kalman Z. 2011: Aquatic beetle and bug assemblages of standing waters with different succesional stages in the floodplain of Drava. - Acta Biol. Debr. Oecol. Hung. 26: $161-178$.

PAPÁČEK M. 2001: Small aquatic and ripicolous bugs (Heteroptera: Nepomorpha) as predators and prey: The question of economic importance. - Eur. J. Entomol. 98: 1-12.

Ribera I., Foster G.N. \& Holt W.V. 1997: Functional types of diving beetle (Coleoptera: Hygrobiidae and Dytiscidae), as identified by comparative swimming behaviour. - Biol. J. Linn. Soc. 61: 537-558.

Ribera I., Vogler A.P. \& Balke M. 2007: Phylogeny and diversification of diving beetles (Coleoptera: Dytiscidae). - Cladistics 24: 563-590.

Rundle S.D., Foggo A., Choiseul V. \& Bilton D.T. 2002: Are distribution patterns linked to dispersal mechanism? An investigation using pond invertebrate assemblages. - Freshw. Biol. 47: $1571-1581$

Sánchez-Fernández D., Abellan P., Mellado A., Velasco J. \& Millan A. 2006: Are water beetles good indicators of biodiversity in Mediterranean aquatic systems? The case of the Segura river basin (Spain). - Biodiv. Conserv. 15: 4507-4520.

Schäfer M.L., Lundkvist E., Landin J., Persson T.Z. \& LundSTRÖM J.O. 2006: Influence of landscape structure on mosquitoes (Diptera: Culicidae) and dytiscids (Coleoptera: Dytiscidae) at five spatial scales in Swedish wetlands. - Wetlands 26: $57-68$.

SCHNEIDER D.W. 1999: Influence of hydroperiod on invertebrate community structure. In Batzer D.P., Rader R.B. \& Wissinger S.A. (eds): Invertebrates in Freshwater Wetlands of North America. Wiley, New York, pp. 299-318.

SchNeIDER D.W. \& Frost T.M. 1996: Habitat duration and community structure in temporary ponds. - J. North Am. Benthol. Soc. 15: 64-86.

StatSoft Inc. 2016: STATISTICA - Data Analysis Software System. Ver. 10. URL: www.statsoft.com.

Ter BraAk C.J.F \& Šmilauer P. 2002: CANOCO Reference Manual and CanoDraw for Windows User's Guide: Software for Canonical Community Ordination (Ver. 4.5). Microcomputer Power, Itaca, $500 \mathrm{pp}$.

Thomas Z., Persson V., Lundström O.J., Petersson E. \& Landin J. 2009: Diving beetle assemblages of flooded wetlands in relation to time, wetland type and Bti-based mosquito control. Hydrobiologia 635: 189-203. 
Turić N., Merdić E., Hackenberger K.B., Jeličić Ž., Vignjević G. \& CSABAI Z. 2012: Structure of aquatic assemblages of Coleoptera and Heteroptera in relation to habitat type and flood dynamic structure. - Aquat. Insect / Int. J. Freshw. Entomol. 34: 189-205.

Turić N., Temunović M., Radović A., Vignjević G., Sudarić Bogojević M. \& Merdić E. 2015: Flood pulse drive the temporal dynamics of assemblages of aquatic insects (Heteroptera and Coleoptera) in a temperate floodplain. - Freshw. Biol. 60: 2051-2065.

Turner A.M. \& Trexler J.C. 1997: Sampling aquatic invertebrates from marshes: Evaluating the options. - J. North Am. Benthol. Soc. 16: 694-709.
Verdonschot R.C.M. 2010: Optimizing the use of activity traps for aquatic biodiversity studies. - J. North Am. Benthol. Soc. 29: $1228-1240$

WILcox C. 2001: Habitat size and isolation affect colonization of seasonal wetlands by predatory aquatic insects. - Israel $J$. Zool. 47: 459-475.

Williams P.H. 1996: Measuring biodiversity value. - World Conserv. 1: 12-14.

Received October 26, 2016; revised and accepted January 31, 2017 Published online February 23, 2017 